\title{
Penyuluhan Kesehatan Jiwa untuk Meningkatkan Pengetahuan Masyarakat tentang Masalah Kesehatan Jiwa di Lingkungan Sekitarnya
}

\author{
Indra Maulana, Suryani, Aat Sriati, Titin Sutini, Efri Widianti, Imas Rafiah, Nur Oktavia Hidayati, \\ Taty Hernawati, Iyus Yosep, Hendrawati, Iceu Amira D.A, Sukma Senjaya \\ Fakultas Keperawatan, Universitas Padjadjaran \\ Email: indra.maulana@unpad.ac.id
}

\begin{abstract}
Abstrak
Menurut data WHO (2016), terdapat sekitar 35 juta orang terkena depresi, 60 juta orang terkena bipolar, 21 juta terkena skizofrenia, serta 47,5 juta terkena dimensia. Di Indonesia, dengan berbagai faktor biologis, psikologis dan sosial dengan keanekaragaman penduduk; maka jumlah kasus gangguan jiwa terus bertambah yang berdampak pada penambahan beban negara dan penurunan produktivitas manusia untuk jangka panjang. Data Riskesdas 2018 menunjukkan prevalensi ganggunan mental emosional yang ditunjukkan dengan gejalagejala depresi dan kecemasan untuk usia 15 tahun ke atas mencapai sekitar $6.1 \%$ dari jumlah penduduk Indonesia. Sedangkan prevalensi gangguan jiwa berat, seperti skizofrenia mencapai sekitar 400.000 orang atau sebanyak 1,7 per 1.000 penduduk. Menurut National Alliance of Mental Illness (NAMI) berdasarkan hasil sensus penduduk Amerika Serikat tahun 2013, di perkirakan 61.5 juta penduduk yang berusia lebih dari 18 tahun mengalami gangguan jiwa, 13,6 juta diantaranya mengalami gangguan jiwa berat seperti skizofrenia, gangguan bipolar. Kondisi ini tidak jauh berbeda dengan permasalahan kesehatan jiwa yang ada di negaranegara berkembang. Tujuan dari pelaksanaan kegiatan pengabdian pada masyarakat ini adalah untuk meningkatkan pengetahuan masyaraakat umumnya dan keluarga yang menjadi binaan khususnya tentang bagaimana cara perawatan dan menjaga kesehatan jiwa setiap masyarakat serta merawat anggota masyarakat yang mengalami gangguan jiwa. Metode yang dipergunakan dalam kegiatan ini adalah ceramah, diskusi dan simulasi. Luaran yang dihasilkan dalam kegiatan pengabdian kepada masyarakat ini adalah pemberdayaan masyarakat tentang kesehatan jiwa. Hasil yang di capai dalam pengabdian ini adalah meningkatnya pengetahuan masyarakat tentang masalah kesehatan jiwa di lingkungan sekitarnya. Kesimpulannya adalah Kegiatan PPM ini telah dilaksanakan dan berdasarkan hasil evaluasi pelaksanaan kegiatan maka diketahui bahwa terjadi peningkatan pengetahuan keluarga tentang masalah kesehatan jiwa yang terjadi di sekitar lingkungannya
\end{abstract}

Kata kunci: Kesehatan jiwa, penyuluhan, warga.

\section{Abstract}

According to WHO data (2016), there are about 35 million people affected by depression, 60 million people affected by bipolar disorder, 21 million affected by schizophrenia, and 47.5 million affected by dementia. In Indonesia, with various biological, psychological and social factors with population diversity; hence the number of cases of mental disorders continues to grow which has an impact on increasing the country's burden and decreasing human productivity for the long term. Riskesdas 2018 data shows the prevalence of mental emotional disorders as indicated by symptoms of depression and anxiety for ages 15 and older reaching around $6.1 \%$ of the population of Indonesia. While the prevalence of severe mental disorders, such as schizophrenia reaches around 400,000 people or as much as 1.7 per 1,000 population. According to the National Alliance of Mental Illness (NAMI) based on the results of the 2013 US population census, it is estimated that 61.5 million people over the age of 18 experience mental disorders, 13.6 million of them experience severe mental disorders such as schizophrenia, bipolar disorder. This condition is not much different from mental health problems that exist in developing countries. The purpose of carrying out community service activities is to increase the knowledge of the general public and the fostered family specifically about how to care for and maintain the mental health of each community and care for community members who experience mental disorders. The methods used in this activity are lectures, discussions and simulations. The output produced in this community service is community empowerment about mental health. The results achieved in this study are increased public knowledge about mental health problems in the surrounding environment. The conclusion is that this PPM activity has been carried out and based on the results of the evaluation of the implementation of the activity, it is known that there is an increase in family knowledge about mental health problems that occur around the environment

Keywords: Citizen, counseling, mental health. 


\section{Pendahuluan}

Orang yang mengalami gangguan Jiwa di Dunia ini sudah banyak dan bahkan di Indonesia pun banyak penderita gangguan Jiwa baik dari kalangan remaja, dewasa, anak-anak sampai orangtua atau lansia mengalami gangguan tersebut. Menurut (Videbeck dalam Prabowo, 2014) berpendapat bahwa gangguan Jiwa adalah keadaan emosi, psikologis, dan sosial yang terpandang dari hubungan komunikasi antar dua orang yang tidak terpenuhi tindakan dan pertahanan yang baik, sesuatu yang dapat dipahami dalam diri yang baik dan keseimbangan emosi yang dalam. Selain masalah gangguan jiwa ada juga masalah psikososial yang biasa terjadi di kalangan masyarakat Indonesia.

Masalah psikososial merupakan masalah yang banyak terjadi dimasyarakat. psikososial adalah suatu kondisi yang terjadi pada individu yang mencakup aspek psikis dan sosial atau sebaliknya. psikososial berarti menyinggung relasi sosial yang mencakup faktorfaktor psikologi. Dari defenisi diatas masalah psikososial adalah masalah yang terjadi pada kejiwaaan dan sosialnya. Psikososial (Psychosocial) adalah hubungan antara kesehatan mental atau emosional seseorang dengan kondisi sosialnya. Istilah psikososial merupakan gabungan antara psikologis dan sosial. Dengan demikian, pengertian perkembangan psikososial adalah perkembangan yang berkaitan dengan emosi atau mental seseorang dalam berhubungan dengan orang lain. Jadi, perkembangan psikososial merupakan perubahan atau perkembangan kepribadian yang berkaitan dengan hubungan sosial

Menurut data WHO (2016), terdapat sekitar 35 juta orang terkena depresi, 60 juta orang terkena bipolar, 21 juta terkena skizofrenia, serta 47,5 juta terkena dimensia. Di Indonesia, dengan berbagai faktor biologis, psikologis dan sosial dengan keanekaragaman penduduk; maka jumlah kasus gangguan jiwa terus bertambah yang berdampak pada penambahan beban negara dan penurunan produktivitas manusia untuk jangka panjang. Data Riskesdas 2018 memunjukkan prevalensi ganggunan mental emosional yang ditunjukkan dengan gejala-gejala depresi dan kecemasan untuk usia 15 tahun ke atas mencapai sekitar $6.1 \%$ dari jumlah penduduk Indonesia. Sedangkan prevalensi gangguan jiwa berat, seperti skizofrenia mencapai sekitar 400.000 orang atau sebanyak 1,7 per 1.000 penduduk. Menurut National Alliance of Mental Illness (NAMI) berdasarkan hasil sensus penduduk Amerika Serikat tahun 2013, di perkirakan 61.5 juta penduduk yang berusia lebih dari 18 tahun mengalami gangguan jiwa, 13,6 juta diantaranya mengalami gangguan jiwa berat seperti skizofrenia, gangguan bipolarJumlah penderita gangguan jiwa dari tahun ke tahun mengalami peningkatan. Kondisi ini tidak jauh berbeda dengan permasalahan 
kesehatan jiwa yang ada di negara-negara berkembang. Tujuan dari pelaksanaan kegiatan pengabdian pada masyarakat ini adalah untuk meningkatkan pengetahuan masyaraakat umumnya dan keluarga yang menjadi binaan khususnya tentang bagaimana cara perawatan dan menjaga kesehatan jiwa setiap masyarakat serta merawat anggota masyarakat yang mengalami gangguan jiwa

Berdasarkan data Riskesdas (2018) diatas, diketahui data penderita gangguan jiwa berat yang cukup banyak di wilayah Indonesia dan sebagian besar tersebar di masyarakat dibandingkan yang menjalani perawatan di rumah sakit, sehingga diperlukan peran serta masyarakat dalam penanggulangan gangguan jiwa. Peran masyarakat dalam penanggulangan gangguan jiwa akan dapat terbangun jika masyarakat memahami tentang peran dan tanggungjawabnya dalam penanggulangan gangguan jiwa di masyarakat.

Banyak masalah-masalah psikososial yang dihadapi oleh keluarga dan masyarakat khususnya daerah perkotaan maupun pedesaan. Menurut Gerald (1983) dalam Hidayati 2018, keluarga menyediakan 3 fungsi dasar sebelum, selama dan setelah masa remaja. 3 fungsi ini tidak sepenuhnya dapat digantikan oleh peergroups / struktur sosial yang lain sepanjang hidup. 3 fungsi tersebut adalah:

1. Keluarga menyediakan 'sense of cohesion' Kohesi ini atau ikatan emosi membuat kondisi untuk identifikasi dengan kelompok dasar yang utama dan meningkat secara emosional, intelektual dan kedekatan fisik.

2. Keluarga menyediakan model kemampuan adaptasi.

Keluarga mengilustrasikan melalui fungsi dasar bagaimana sebuah struktur kekuatan dapat berubah, bgaimana peran hubungan dapat berkembang dan begaimana peraturan hubungan dapat terbentuk. Remaja yang memiliki pengalaman tipe keluarga yang rigid (rendah tingkat adaptasinya) cenderung terinternalisasi gaya interaksi yang rigid. Sebaliknya, terlalu banyak kemampuan adaptasi dapat membuat gaya \&lsquo;chaotic\&rsquo;. Keseimbangan penting untuk fungsi ini, hal yang sama juga dengan kohesi.

3. Keluarga menyediakan sebuah jaringan komunikasi.

Melalui pengalaman dimana individu belajar seni dari pembicaraan, interaksi, mendengarkan dan negosiasi. Pengkajian psikososial pada keluarga dilakukan di di RW 18, RW 7, dan RW 12 Desa Cipacing, Kecamatan Jatinangor, Sumedang. 
Berdasarkan hasil studi pendahuluan terdapat 27 klien yang mengalami gangguan kejiwaan di Desa Cipacing. Masalah Psikososial di 3 RW di desa Cipacing terdapat 50 orang.

\section{Metode}

Kegiatan pertama yang dilakukan adalah melaksanakan identifikasi permasalahan yang dialami oleh masyarakat dan keluarga tentang kesehatan jiwa. Permasalahan permasalahan yang telah diidentifikasi kemudian dilakukan analisis dan hasil analisis kemudian disusun dalam skala prioritas masalah yang harus diselesaikan. Masalah yang terpilih sebagai prioritas utama kemudian diselesaikan bersama dengan keluarga dengan pemberian pendidikan kesehatan dan menggunakan metode ceramah, diskusi, simulasi serta role play. Jumlah populasi dalam kegiatan ini adalah 57 orang peserta yang datang pada waktu penyuluhan, dan dilakukan pemberian kuisioner sebagai pretest untuk mengetahui sejauh mana pengetahuan peserta ketika sebelum melakukan penyuluhan, setelah selesai penyuluhan peserta diberikan lagi kuisioner pertanyaan yang disebut post test. Data yang diperoleh dari kuisioner selanjutnya dilakukan analisis menggunakan $\mathrm{t}$ test berpasangan dan uji korelasi regresi

\section{Hasil}

Kegiatan PPM Mandiri yang telah dilaksanakan adalah identifikasi permasalahan yang dihadapi oleh masyarakat dan keluarga ODGJ tentang kesehatan jiwa didesa cipacing kecamatan Jatinangor melakukan analisis data hasil identifikasi permasalahan keluarga dalam mengatasi kecemasan di rumah dan menetapkan skala prioritas pada masalah yang telah ditemukan, serta melakukan pendidikan kesehatan sebagai salah satu solusi permasalahan prioritas yang dialami oleh keluarga di rumah.

Tabel 1 Evaluasi proses penyuluhan tentang perawatan Kesehatan Jiwa di masyarakat

\begin{tabular}{lll}
\hline & Sebelum Penyuluhan & Setelah Penyuluhan \\
\hline Pengetahuan & $-20 \%$ keluarga dapat & $-80 \%$ keluarga dapat \\
keluarga tentang & menjelaskan kesehatan & menjelaskan \\
kesehatan jiwa bagi & jiwa bagi masyarakat & pentingnya \\
masyarakat yang & yang mengalami & perawatan kesehatan \\
mengalami & gangguan psikososial & jiwa yang tepat pada \\
gangguan & di rumah dengan tepat & masalah psikososial \\
psikososial di & & di rumah \\
rumah & &
\end{tabular}




\begin{tabular}{|c|c|c|}
\hline $\begin{array}{l}\text { Antusiasme } \\
\text { keluarga dalam } \\
\text { mengikuti kegiatan } \\
\text { penyuluhan }\end{array}$ & $\begin{array}{l}\text { - } 80 \% \text { keluarga } \\
\text { antusias dalam } \\
\text { mengikuti kegiatan }\end{array}$ & $\begin{array}{l}-90 \% \text { keluarga } \\
\text { diakhir kegiatan } \\
\text { antusias mengikuti } \\
\text { kegiatan }\end{array}$ \\
\hline
\end{tabular}

\section{Tabel 2 Nilai rata-rata pre-test dan post- kesehatan jiwa menjadi energi positif} $(n=68)$

\begin{tabular}{lcc}
\hline & Pre-test (\%) & Post-test (\%) \\
\hline Pengetahuan masyarakat & 35 & 85 \\
\hline
\end{tabular}

Berdasarkan nilai rata rata kemampuan pengetahuan masyarakat tentang mengubah kecemasan menjadi energi positif di rumah mengalami peningkatan $60 \%$

\section{Pembahasan}

Perawatan Kesehatan jiwa di desa cipacing masih mengandalkan petugas kesehatan dan tidak secara mandiri untuk dilakukan perawatan oleh keluarga Berdasarkan fakta fakta permasalahan kesehatan jiwa tersebut, World Health Organization (WHO) dan World Federation for Mental Health (WFMH) berupaya menekankan penyelesaian permasalahan kesehatan jiwa dari akarnya, yang dituangkan ke tema Hari Kesehatan Jiwa Sedunia 2016. Mengambil tema Martabat dalam Kesehatan Jiwa: Pertolongan Pertama Psikologis dan Kesehatan Jiwa Bagi Semua dengan sub tema Jiwa yang Sehat Berawal dari Keluarga Sehat; maka pesan utama yang ingin disampaikan adalah bahwa setiap orang memiliki hak untuk dihargai dan mendapatkan perlakuan layak sesuai dengan harkat dan martabat sebagai manusia (Depkes, 2016) yang dilakukan oleh Badan Penelitian Pengembangan Kesehatan Departemen Kesehatan, menunjukkan prevalensi gangguan jiwa di Indonesia sebesar 1.7 permil, artinya dari 1000 penduduk Indonesia, maka satu sampai dua orang diantaranya menderita gangguan jiwa. Banyaknya jumlah penderita gangguan jiwa di Indonesia ini tersebar di seluruh wilayah Indonesia, termasuk di provinsi Jawa Barat.

World Health Organitation (2001) menjelaskan bahwa gangguan jiwa merupakan sekumpulan gangguan pada fungsi pikir, emosi, perilaku dan sosialisasi dengan orang sekitar. Angka kekambuhan skizofrenia mengalami kenaikan pada tahun 2017. Tingginya 
angka kekambuhan pada skizofrenia disebabkan karena beberapa faktor, salah satu faktor yang berperan sangat penting adalah hubungan pasien dengan keluarga (Prabowo, 2010). Sedangkan Videbeck (2013) dalam Widianti 2018 mendefinisikan gangguan jiwa berat sebagai gejala gangguan mental berat di mana seseorang kehilangan kemampuan untuk mengenali realitas, berhubungan dengan orang lain,dan berperilaku aneh.

Peningkatan jumlah populasi penduduk dunia yang menderita gangguan jiwa menimbulkan dampak bagi keluarga dan masyarakat. Dampak yang ditimbulkan oleh gangguan jiwa dapat dibedakan menjadi dampak secara sosial dan dampak secara ekonomi. Dampak secara sosial dapat berupa pengucilan, hinaan, ejekan, dipisahkan dari lingkungan serta menimbulkan ketakutan masyarakat (Lee et al) dalam Widianti 2018. Sedangkan dampak secara ekonomi adalah menurunnya produktivitas pasien dengan gangguan jiwa dan caregivernya, adanya beban ekonomi dan menurunnya kualitas hidup (Sadock \& Sadock, 2007). Besarnya beban yang harus ditanggung oleh keluarga, masyarakat dan negara akibat meningkatnya penderita gangguan jiwa ini perlu mendapat perhatian yang serius dengan berupaya meningkatkan pengetahuan dan pemahaman tentang gangguan jiwa dan berupaya untuk bisa mencegah dan mengatasinya.

Upaya pencegahan dan penanggulangan gangguan jiwa di masyarakat adalah tugas bersama masyarakat beserta perangkatnya dan petugas kesehatan yang berada di wilayah kerja puskesmas setempat. Upaya pencegahan ini dapat dilakukan dengan beberapa tahapan. Tahapan pertama adalah dengan melakukan pendekatan kepada perangkat wilayah setempat, dan tokoh masyarakat di wilayah setempat, tahap berikutnya adalah melakukan psikoedukasi kepada perangkat wilayah setempat sehingga didapatkan pemahaman yang sama antara petugas kesehatan dan perangkat wilayah serta tokoh masyarakat tentang pentingnya kepedulian terhadap anggota masyarakat dengan ganguan kejiwaan. Tahap berikutnya adalah perangkat wilayah dan tokoh masyarakat menetapkan wakil dari wilayah bertugas menjadi fasilitator bagi masyarakat dalam upaya penanggulangan gangguan jiwa di masyarakat. Perwakilan masyarakat yang mengurusi masalah kesehatan jiwa masyarakat ini selanjutnya disebut sebagai kader kesehatan jiwa. selanjutnya kader kesehatan jiwa yang telah ditetapkan mengikuti pelatihan kader kesehatan jiwa untuk meningkatkan pengetahuan dan keterampilan dalam mencegah dan menanggulangi gangguan jiwa di masyarakat sesuai dengan peran dan fungsinya, tugas selanjutnya yang diemban oleh kader kesehatan jiwa adalah melakukan deteksi dini gangguan jiwa sebagai langkah awal untuk melakukan 
pemetaan masalah kesehatan jiwa di masyarakat sehingga dapat di tentukan langkah langkah pencegahan dan penanggulangan lebih lanjut. Peran yang dijalankan oleh kader kesehatan jiwa ini akan dapat berjalan dengan optimal ketika ada dukungan optimal pula oleh petugas kesehatan di puskesmas terkait dan masyarakat secara umum termasuk didalamnya keluarga klien dengan gangguan jiwa, sehingga harapan terwujudnya masyarakat sehat jiwa produktif dapat menjadi sebuh kenyataan

\section{Simpulan}

Kegiatan PPM ini telah dilaksanakan dan berdasarkan hasil evaluasi pelaksanaan kegiatan maka diketahui bahwa terjadi peningkatan pengetahuan keluarga tentang pentingnya energi positif untuk mengatasi kecemasan pada masyarakat desa Cipacing.

\section{Ucapan Terima kasih}

Dengan selesainya PKM ini kami ucapkan terima kasih kepada Masyarakat desa Cipacing, Kader, Tokoh Masyarakat, puskesmas Jatinangor, dan perangkat desa yang telah ikut serta dalam mensukseskan kegiatan ini

\section{Daftar Pustaka}

Depkes RI. (2019). Riset Kesehatan Dasar 2018. Jakarta. Badan Penelitian dan Pengembangan Kesehatan Republik Indonesia.

NIMH.(2000). American Psychiatric Associations. http://www.nimh.nih.gov/statistics/. diperoleh tanggal 15 Maret 2013

NIMH. (2011). Prevalence of Mental Ilness by Disorder. http://www.nimh.nih.gov/statistics/. diperoleh tanggal 15 Maret 2013

Hidayati, N. O., Widianti, E., Sriati, A., Sutini, T., Rafiyah, I., Hernawaty, T., \& Suryani, S. (2018). Pelatihan Perencanaan Diri Terhadap Orientasi Masa Depan Remaja di Lembaga Pembinaan Khusus Anak (LPKA). Media Karya Kesehatan, 1(2).

Prabowo, E. (2014). Konsep \& Aplikasi Asuhan Keperawatan Jiwa. Nuha medika.

Saddock, B.J dan Saddock, V.A (2007). Kaplan and Saddock's synopsis of psychiatry: Behavioral science/clinical psychiatry. 10th Ed. Lippincott William \& Wilkins.

WHO. (2006). The lancet. London : Elsevier Properties SA. 
WHO. (2009). Improving health system and service for mental health : WHO Library Cataloguing-in-Publication Data.

Widianti, E., Hernawaty, T., Sutini, T., Sriati, A., Hidayati, N. O., \& Rafiyah, I. (2018). Pembentukan Self Help Group Keluarga Orang Dengan Ngangguan Jiwa (ODGJ). Media Karya Kesehatan, 1(2).

World Health Organization, World Organization of National Colleges, Academies, \& Academic Associations of General Practitioners/Family Physicians. (2008). Integrating mental health into primary care: a global perspective. World Health Organization.

http://www.depkes.go.id/article/print/16100700005/peran-keluarga-dukung-kesehatan-jiwamasyarakat.html 